\title{
Correction to: Reliability: understanding cognitive human bias in artificial intelligence for national security and intelligence analysis
}

\author{
Gaudys L. Sanclemente ${ }^{1,2,3,4}$ (D) \\ Published online: 1 December 2021 \\ (C) Springer Nature Limited 2021

\section{Correction to: Security Journal https://doi.org/10.1057/s41284-021-00321-2}

After publication it was noticed, Benjamin N. Cardozo should be deleted from the author group and the affiliation of the four universities should be mentioned by the corresponding author name Gaudys L. Sanclemente. The original article has been updated accordingly.

Publisher's Note Springer Nature remains neutral with regard to jurisdictional claims in published maps and institutional affiliations.

The original article can be found online at https://doi.org/10.1057/s41284-021-00321-2.

Gaudys L. Sanclemente

glsanclementefl@flacso.edu.ec

1 Latin American Faculty of Social Sciences (FLACSO), Department of International Studies and Communications, Quito, Ecuador

2 Benjamin N. Cardozo School of Law, New York, NY, USA

3 Western Michigan University Cooley Law School, Lansing, MI, USA

4 Stony Brook University, Stony Brook, NY, USA 